Research article

\title{
CROSSTALKS AMONG CANCER STEM CELLS AND HISTOPATHOLOGIC FEATURES IN DETERMINING PROGNOSIS IN CANINE MAMMARY GLAND CARCINOMAS
}

\author{
Havva MARZBAN ${ }^{1 *}$, Gelareh CHAMANI $^{2}$, Fariba $\mathrm{KHAKI}^{3}$, Parnian $\mathrm{AMINI}^{4}$, \\ Nastaran PEDRAM ${ }^{5}$, Zeinab ASGHARI ${ }^{3}$, Mohammadreza BOROOMAND ${ }^{6}$, \\ Samira MORADI ${ }^{7}$, Artimes YAHYAEI ${ }^{8}$, Mersedeh Sadat HOSSEIN \\ BOROUJERDI $^{8}, \mathrm{Kamyab}$ VALINEZHAD ${ }^{9}$
}

\begin{abstract}
${ }^{1}$ Department of Pathology and Experimental Animals, Razi Vaccine and Serum Research Institute, Agricultural Research, Education and Extension Organization (AREEO), Karaj, Iran; ${ }^{2}$ Department of Basic Science, Islamic Azad University Central Tehran Branch, Ayatollah Hashemi Rafsanjani Complex, Tehran, Iran; ${ }^{3}$ Healthy Pet Animal Hospital, Karaj, Alborz, Iran; ${ }^{4}$ Department of Veterinary Laboratory Science, Islamic Azad University, Rasht Branch, Rasht, Iran; ${ }^{5}$ Department of Clinical Science, School of Veterinary Medicine, Shiraz University, Shiraz, Iran; 'Department of Basic Science, Islamic Azad University Jahroom Branch, Shiraz, Iran; ${ }^{7}$ Department of Medicine, Faculty of Medical Science, Hormozgan University, Iran; ${ }^{8}$ Department of Surgery and Radiology, Faculty of Veterinary Medicine, University of Tehran, Iran; ${ }^{9}$ Higher Educations Institute of Estahban, Fars, Iran
\end{abstract}

(Received 25 May, Accepted 23 August 2021)

The purpose of the present work was the evaluation of the prognostic potential of histopathologic features, cancer stem cells (CSCs), and epthelial-mesenchymal transition (EMT) in relation to lymph node status and lymphovascular invasion (LVI) in canine mammary gland carcinomas (CMGCs). CSCs are proposed as the main cause of tumorigenesis, therapy failure, and recurrence which form a small fraction of tumor bulk. We evaluated presence of micropapillary growth pattern (MGP), infiltration into surrounding tissues (IST), and vasculogenic mimicry (VM) in H\&E stained slides of 26 paraffin-embedded tumor samples. Lymph nodes of all cases were assessed. Additionally, they were examined immunohistochemically in terms of vimentin expression as an indicator of EMT which is a well-known mechanism for metastasis, and CD44, CD24, and ALDH1 for CSCs detection. Data analyses showed significant relationships between MGP and CSCs $(\mathrm{P}=0.037)$, VM and CSCs $(\mathrm{P}=0.013)$, lymph node status and CSCs $(\mathrm{P}=0.0001)$, lymph node status and EMT $(\mathrm{P}=0.003)$, IST and LVI $(\mathrm{P}=0.05), \mathrm{VM}$ and LVI $(\mathrm{P}=0.01), \mathrm{VM}$ and lymph node status $(\mathrm{P}=0.007)$, and LVI and lymph node status $(\mathrm{P}=0.04)$. Results indicated the prognostic value of MGP, VM, and CSCs with respect to confirmed prognostic markers, including LVI and lymph node involvement, in CMGCs.

Keywords: cancer stem cells, canine, carcinoma, epithelial-mesenchymal transition, immunohistochemistry, animal model

\footnotetext{
*Corresponding author: e-mail: Havva.marzban@gmail.com
} 


\section{INTRODUCTION}

Canine mammary gland cancers (CMGCs) account for nearly $50 \%$ of all diagnosed mammary tumors in bitches which are comparable to human breast cancers (HBCs) known as the leading cause of mortality [1,2]. Growing body of evidence is indicative of significant similarities between CMGCs and HBCs regarding heterogeneity, histopathologic, and biologic features emphasizing the significance of comparative oncology in terms of exploring novel therapeutic approaches and enhancing therapy efficacy that could be beneficiary to both groups $[1,3,4]$.

Cancer cell dormancy, therapy resistance, metastases, and subsequent poor outcome result in almost 90\% of recurrence-related deaths [4-6]. Multiple hypotheses are suggested for tumor recurrence including cellular dedifferentiation, stemness induction, and acquiring aggressive histopathologic forms among others [2]. The metastatic ability of CMGCs is commonly evaluated according to TNM classification of malignant tumors (TNM staging) and tumor histopathologic characteristics, such as histotype, tumor grade, and lymphovascular invasion (LVI) [4]. Apart from these confirmed methods, other histologic criteria namely micropapillary growth pattern (MGP), infiltration to surrounding tissue (IST), and vasculogenic mimicry (VM) have been proposed as putative predictors [2].

MGP is characterized by the presence of tumor cells forming papillae without fibrovascular stalks and highly likely to invade the lymphatic system leading to tumor cells dissemination. IST known as invading cancer cells to surrounding tissues has been shown to have a prognostic value in CMGCs [2,7]. Another probable invasive determinant is called VM in which epithelial cells acquire the endothelial phenotype and provide themselves with more blood supply and a way of escape, survive and spread in challenging environments [8]. VM is diagnosed when a neoplastic cell forms a cytoplasmic channel that might contain blood cells or empty space indicative of a root for lymphatic invasion [2]. Cancers with VM show aggressive behavior and have a poorer outcome compared with tumors devoid of it [9].

Epithelial-mesenchymal transition (EMT) has been suggested as one of the most important mechanisms responsible for metastasis and eventual recurrence. This phenomenon can be assessed via evaluation of the vimentin expression in immunostained tissue sections. Vimentin is an intermediate filament, confers to the epithelial cancer cells their invasive capacity to separate from the whole tumor mass and increases metastatic distribution [8-10].

A small fraction of the tumor bulk is called cancer stem cells (CSCs) is proposed as the main contributor to dormancy and metastatic spread which can happen prior to development of a detectable primary mammary mass and they can seed in the bone marrow or other favorable niches as disseminated tumor cells (DTCs) [5]. To survive in unfavorable environments, CSCs make advantage of different dissemination stratagies such as different modes of motility and acquire quiescence $[4,11,12]$. One of 
these strategies is EMT enabling CSCs to survive and emerge lethal metastatic circuits which course can stretch from months to decades [12-14].

EMT and CSCs share different cell signaling pathways and transcriptional factors which could build complex positive feedback loops, making the patient's condition worse $[15,16]$.

Up to our knowledge, this is the first study which evaluated the prognostic significance of MGP, IST, and VM in relation to CSCs, EMT, LVI, and lymph node involvement in CMGCs. The second objective was to investigate different correlations among CSCs and lymph node status and among EMT and lymph node metastases. The third objective was to clarify the value of CMGCs as the most appropriate model in preclinical trials for HBCs.

\section{MATERIAL AND METHODS}

\section{Tumor samples and histopathologic evaluation}

In this study, 26 cases of CMGCs were collected between January 2017 and January 2020. They were fixed, processed, blocked in paraffin, and cut in $4 \mu \mathrm{m}$ sections; thereafter, all slides were stained with hematoxylin-eosin (H\&E). According to Meuten (2016), our analyzes comprised intraductal papillary carcinoma (5 cases), tubular carcinoma (8 cases), tubulopapillary carcinoma (6 cases), complex carcinoma ( 2 cases), solid carcinoma ( 3 cases), anaplastic carcinoma (1 case), and inflammatory carcinoma (1 case) [17]. Given findings of MGP, IST, and VM in all tissue samples, histopathologic evaluation was carried out.

Lymph nodes of all cases were assessed by H\&E staining via light microscopy. Presence of isolated tumor cells $(<0.2 \mathrm{~mm})$, micrometastasis $(0.2-2 \mathrm{~mm})$, and macrometastasis $(>2 \mathrm{~mm}$ ) were defined as lymph node involvement, otherwise they were accounted negative. LVI was defined by the presence of cancerous cells in the lumen of lymphatics or blood vessels.

\section{Immunohistochemistry assessment}

To examine EMT and CSCs in tumor samples, the paraffin-embedded blocks were cut at a thickness of $3 \mu \mathrm{m}$. The slides were deparaffinized, rehydrated, immersed in hydrogen peroxide for endogenous peroxidase blockade, and then exposed to heatinduced antigen retrieval. The slides were subjected to primary antibodies, namely vimentin (Sc-373717; Vimentin (E-5), dilution: 1:50-1:500) as an EMT indicator, CD44 (NBP1-47386; CD44 antibody (8E2F3), dilution: 1:200-1:1000), CD24 (Sc-19651; Rat monoclonal antibody (M1/69), dilution: 1:50-1:500), and ALDH1 (Sc-166362; Mouse monoclonal antibody (H-8), dilution: 1:50-1:500) for CSCs detection, thereafter secondary antibody and HRP detection kits were used according to manufacturer's protocol (Biocare Medical, California, USA). Betazoid DAB was applied for the 
amplification of antigen-antibody reactions. Immunostaining results for vimentin were defined based on the percentage of positive cells and intensity of reaction in 1,000 cells in $10 \mathrm{HPF}(\times 400)$. Fibroblastic and endothelial cells were considered as internal negative controls.

\section{Statistical analyses}

SPSS software (v. 24; Armonk, NY: IBM Corp (2016), USA) was used for data analysis and correlations between quantitative and qualitative parameters were assessed by $t$ test and Chi Square test, respectively. It should be noted that $P$-value $<0.05$ was considered significant.

\section{RESULTS}

\section{Histopathologic features and their relations with CSCs, LVI, and lymph node status}

In $38.4 \%$ of tumor samples (10 of 26), neoplastic cells arranged in a micropapillary growth pattern (Figure 1). Interestingly, none of solid mammary gland carcinomas exhibited this arrangement, and more than half of the tubulopapillary carcinomas, as is appreciated from their name, showed this structure. MGP was detected only in one intraductal papillary carcinoma (case 4) and one complex carcinoma (case 25).

Infiltrative tumor cells to adjoining tissues were diagnosed in $88.4 \%$ of cases $(23$ of 26); most notably all tubular carcinomas, all solid types, all complex carcinomas, inflammatory and anaplastic carcinomas showed IST (Figure 2). Also, this pattern was found in $83.3 \%$ of tubulopapillary carcinomas and more than half of intraductal papillary carcinomas.

VM was observed in 62.2\% (18 of 26) of cases (Figure 3) with different histotypes including one inflammatory carcinoma, one anaplastic carcinoma, 87.5\% of tubular carcinomas, $40 \%$ of intraductal papillary carcinomas, $83.3 \%$ of tubupapillary carcinomas, and $66.6 \%$ of solid carcinomas (Table 1). VM was detected in $54.5 \%$ tumors grade I (6 of 11), 75\% grade II (9 of 12), and 100\% grade III (3 of 3).

Lymph node evaluation showed $30.7 \%$ (8 of 26) involvement which all of them were categorized as macro- and micrometastases.

Association between MGP and CSCs was significant $(\mathrm{P}<0.05)$. It is noteworthy that cases without MGP mostly belonged to CSC negative group. Additionally, a significant association was found between VM and CSCs $(\mathrm{P}<0.05)$, and cases without VM were mostly found in the CSC negative group. There was no significant correlation between IST and CSCs $(\mathrm{P}>0.05)$.

A positive correlation was observed between IST and LVI $(\mathrm{P} \leq 0.05)$, as IST positive cases depicted more invasions into the lymphovascular system compared to samples without it. Additionally, LVI and lymph node status showed a statistically significant relationship $(\mathrm{P}<0.05)$. 


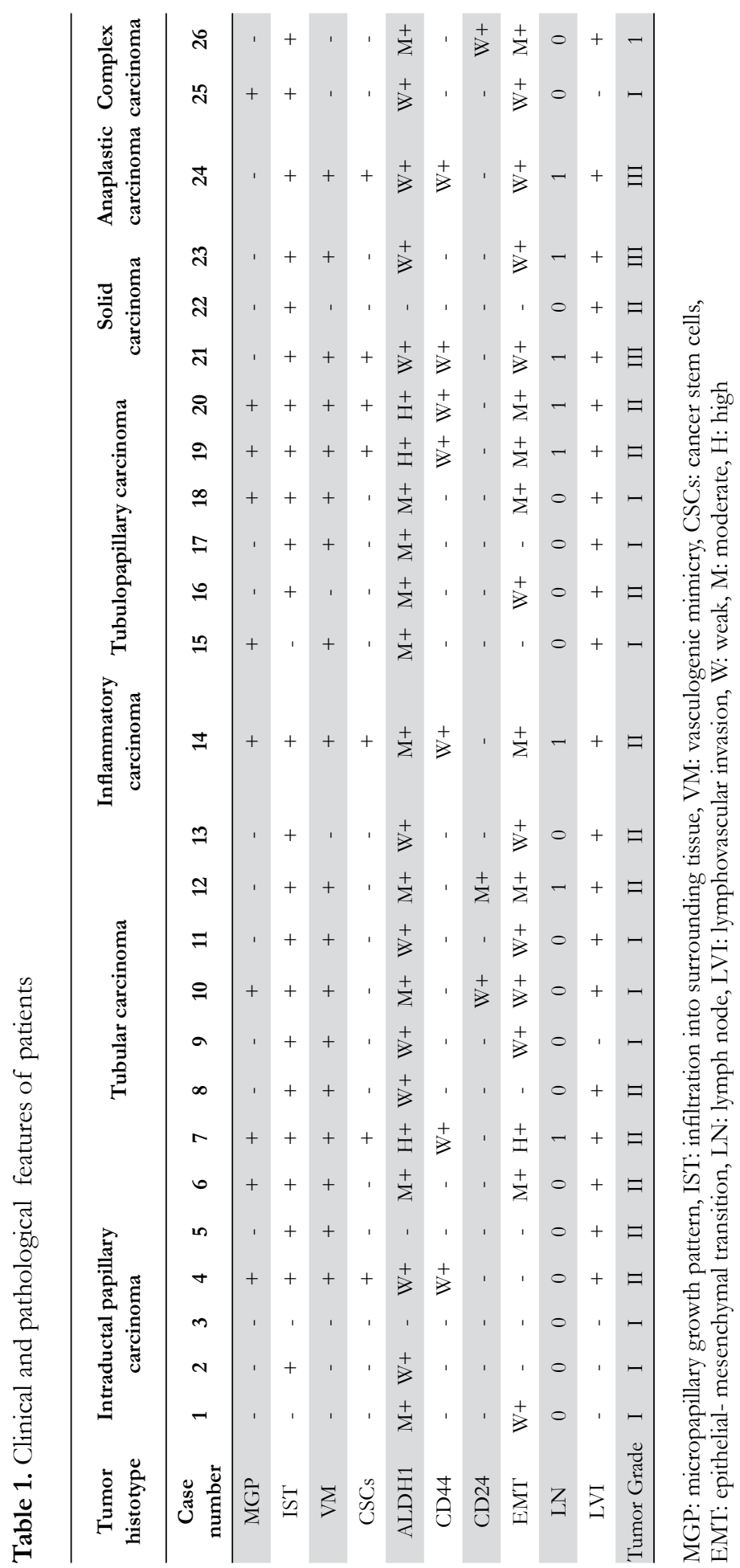


LVI positivity was shown more commonly in tumor samples with VM and it showed significant differences between cases possessing both VM and LVI positivity, and cases not presenting these features $(\mathrm{P} \leq 0.01)$.

Interestingly, a significant positive correlation was found between VM and lymph node status $(\mathrm{P}<0.01)$, so that almost all tumors devoid of VM did not show any lymph node involvement. None of two other histologic features were statistically significant in relation to lymph node involvement $(\mathrm{P}>0.05)$.

\section{Immunohistochemistry}

\section{The prognostic potentials of CSCs and EMT}

Vimentin as an EMT indicator expressed in the cytoplasm of cancer cells (Figure 4). In this work, $30.7 \%$ of all cases were negative which included intraductal papillary

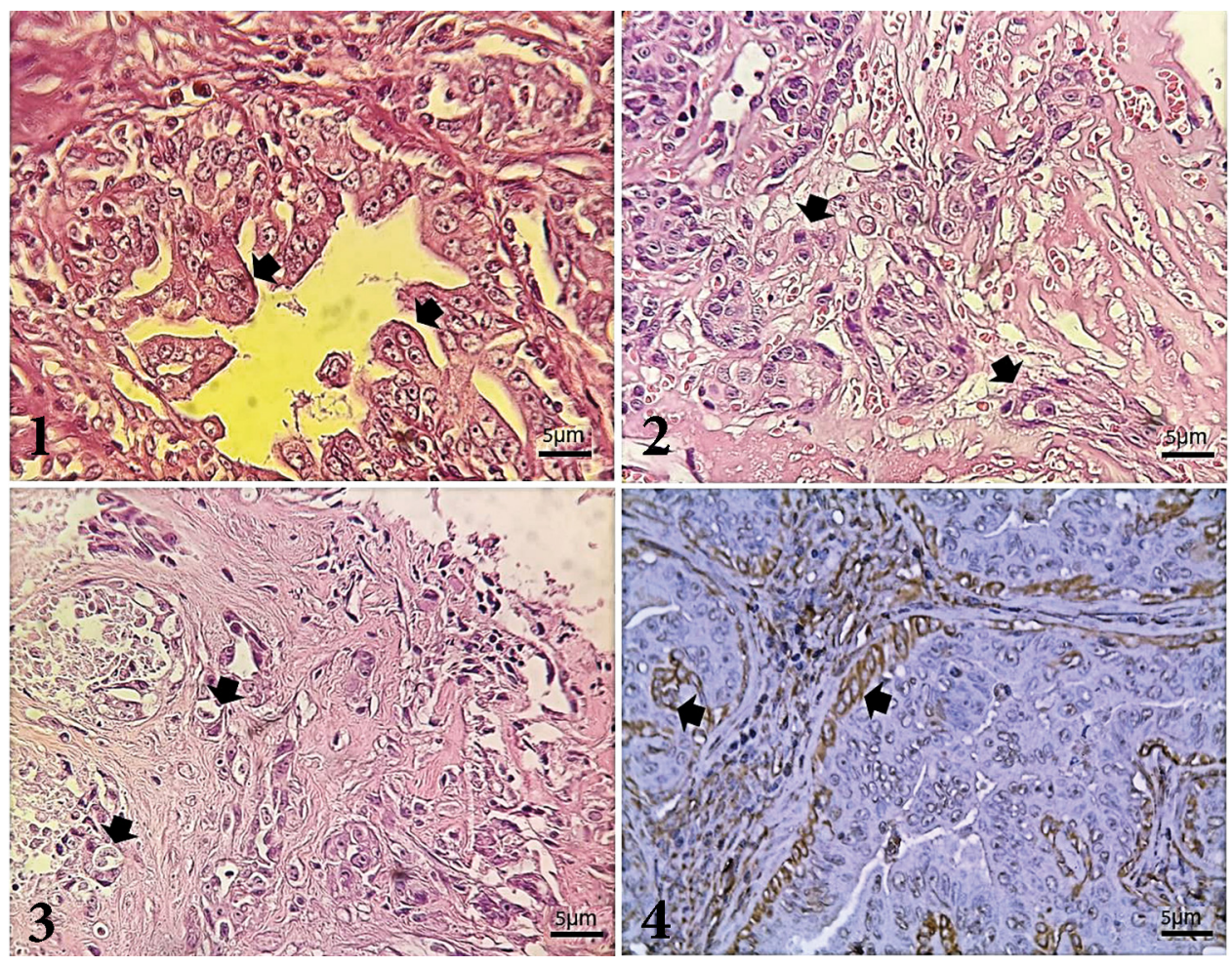

Figure 1. Micropapillary growth pattern in tubulopapillary mammary gland carcinoma; neoplastic cells are arranged in a papillary pattern without any fibrous stalk; dog, 400X. H\&E. Figure 2. Infiltration to surrounding tissues in solid mammary gland carcinoma; invasive cancer cells escape and spread to adjacent tissue; dog, 400X. H\&E.

Figure 3. Vasculogenic mimicry in intraductal papillary mammary gland carcinoma; multiple neoplastic cells in this field show a channel like structure mimicking vasculatures; dog, 400X. $\mathrm{H} \& \mathrm{E}$.

Figure 4. High expression of Vimentin in epithelial cancer cells. Tubulopapillary mammary gland carcinoma; dog.400X. IHC 
carcinoma (4 of 5), tubular carcinoma (1 of 8), tubulopapillary carcinoma (2 of 6 ), and solid carcinoma (1 of 3). Only one of these EMT negative cases was CSC positive (Figure 5). Remaining cases (69.2\%) showed different levels of vimentin expression as follows: $42.3 \%$ weak, $23 \%$ moderate, and 4\% highly positive. Only one case with tubular histology and high positive vimentin expression was CSC positive.

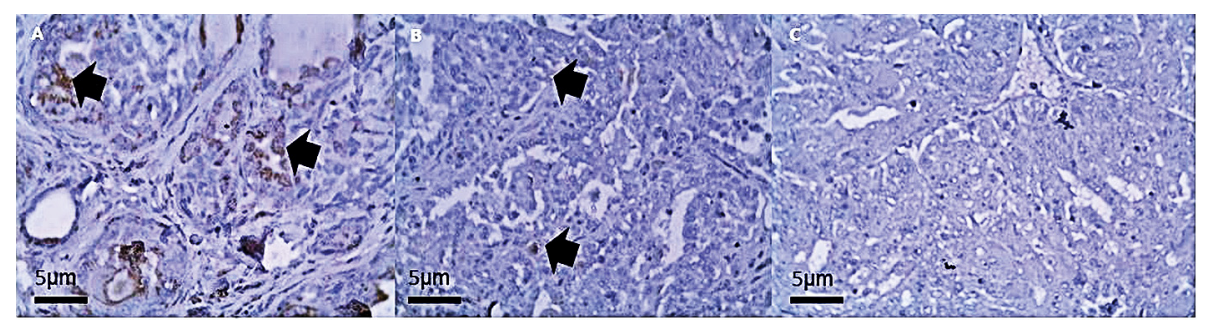

Figure 5. Immunohistochemical detection of CSCs in Tubulopapillary mammary gland carcinoma. A) ALDH1 strong expression in the cytoplasm of epithelial cancer cells. B) CD44 weak expression in the membrane of epithelial cancer cells. C) CD24 negative expression in the epithelial cancer cells. Dog, 400x. IHC

Among confirmed prognostic factors, namely lymph node status and LVI, vimentin expression presented a significant positive relation with lymph nodes $(\mathrm{P}<0.01)$ and no significant correlation with LVI (P > 0.05).

Ather significant associations were shown between concurrent presence of CSCs and EMT, and LVI positivity $(\mathrm{P}<0.05)$, and also with lymph node involvement $(\mathrm{P}<0.01)$.

The vitally important aspect of this data was that $85.7 \%$ of CSC positive tumors presented lymph node involvement and a significant correlation was observed between CSCs and lymph node status $(\mathrm{P}<0.01)$.

\section{DISCUSSION}

Although potential prognostic indicators have been progressively expanded, recurrenceand metastases-related deaths are still the main challenge in CMGCs and HBCs. The present study was designed to evaluate some probable indicators of patients' outcome and their relations with given prognostic factors like LVI and lymph node status.

Among the studied variations, only VM showed significant correlation with lymph node involvement and was detected in all histotypes examined in this study, except for complex carcinoma. Clemente et al. reported the presence of VM in canine tubular carcinoma, papillary carcinoma, inflammatory carcinoma, and anaplastic carcinoma with highly aggressive behavior; which is in accordance with the findings of our study [18]. On the other hand, Rasotto et al. reported the presence of VM only in anaplastic carcinomas and did not find any significant association between this feature and lymph node positivity and LVI [2]. Other studies showed a positive correlation between VM and higher TNM staging, particularly with more metastases to lymph nodes in head 
and neck carcinomas, and proposed VM as a practical prognostic criterion that can be incorporated to routine cancer practice [19]. This association seems to have stemmed from the use of adapting strategy by aggressive transformed cells to fulfill their needs, particularly in unfavorable environments [19-21]. Some authors have speculated that CSCs with their unique cellular plasticity and adaptation strength might mimic vascular structure independent of endothelial cells which are suggestive of synergistic effects of concurrent existence of CSC markers and VM on patient outcome [18,21-23].

The most important clinically relevant finding was a significant correlation between VM and CSCs. Prado et al. presented prognostic significance of VM in CMGCs [22]. This association can be justified by common regulatory genes shared among stemness induction, angiogenesis, and VM pathways, since enhancing CSCs population leads to increasing VM and propensity to spread and metastasis in bidirectional interactions $[21,24]$. The observed significant correlation between VM and LVI might be explained with an intermediary role for LVI connecting VM appearance and CSCs dissemination, which altogether result in metastatic seeding and cancer propagation [25-28]. Early studies have reported the importance of VM, as it provides progressive tumors with supportive microcirculation which is eventually connected to the general circulation. Therefore, it is clear that this feature can enhance the invasive propensity of malignant cells with tumorigenic potential [5,26]. VM supplies lymphatic and hematogenous routes of breast cancer spread, since some cases demonstrated VM, but not lymph node involvement, in which cancer cells liberate and spread hematogenouslly, and lodge in bone marrow in dormant state as DTCs [29].

In the presented study, there were no statistically significant differences among low, intermediate, and high grade of CMGCs and VM appearance. Similarly, Ahmadi et al. reported no significant relationship between tumor grades and VM in prostatic adenocarcinomas [30]. On the other hand, Zhao et al. described the presence of VM even in grade I hepatocellular carcinomas [31].

Another important finding in the current research was a significant relationship between IST and LVI which was in agreement with Aleskandarany et al. regarding the presence of cellular aggregates or single cells invading to surrounding ECM [32]. In contrast to the accumulated evidence suggestive of the pivotal role of EMT in the invasive front of tumors, this study could not find any evidence of a significant association between IST and EMT which could be attributed to other possible modes of mobility, such as filopodia and protursions, or amoeboid movements [32,33]. Flexibility in migratory modes has stemmed from coping cancer cells to acquire the best way of dissemination [11]. Rasotto et al. emphasized the significance of entrapped invasive cells in desmoplastic surrounding stroma which is noticed in the present work [2]. Desmoplastic reactions resulting from dynamic interactions among distinct cellular components of the tumor microenvironment can facilitate cell migration by granting them favorable and permissive conditions [2,34]. It is noteworthy that confining environments lead to shifting the mesenchymal phenotype to speedy amoeboid migration mode which is justifiable by desmoplastic stroma encircling migratory cells 
[33,35]. In accordance with the present results, previous studies have demonstrated the prognostic potential of IST and a positive relationship with lymphatic system invasion [2].

The results indicate a significant positive relationship between MGP and CSCs which is consistent with Yang et al. findings who reported increased number of CSCs bearing $\mathrm{CD}_{4} 4^{+} / \mathrm{CD} 24^{-/ \text {Low }}$ phenotype accompanied by micropappilary histotype, enhanced metastatic potential, and a worse outcome [36].

Invasive micropapillary carcinoma as a distinct entity is associated with higher rates of LVI and lymph node involvement [36]. However, MGP can be detected as a component in different malignancies including CMGCs, HBCs, lung, and colorectal cancers. MGP mostly appeared as a transitory form of other histologic patterns preferably at the invasive front of tumors associated with bigger tumor size, advanced clinical stages, and perineural and lymphovascular invasions [36,37]. These highly aggressive features can be attributed to the increased number of CSCs compared to less aggressive counterparts. Despite possessing better overall survival compared to ductal carcinoma in situ, invasive micropapillary carcinomas have a shorter recurrence free period because of a higher frequency of loco-regional relapses [7,38]. This feature could be justified by compounding effects of CSCs presence and the invasive histologic pattern, thus accelerating the release of disseminating cells and metastatic disease development.

In this work, LVI and lymph node status showed a significant correlation. In accordance with the present result, previous studies have demonstrated that LVI as a strong substitute for lymph node status could significantly predict patients' clinical outcome and LVI positive cancers are accompanied by aggressive clinical, molecular, and histopathologic characteristics [39-43]. According to clinical TNM staging, node involvement has its own effect on prognosis, and LVI assessment can be a valuable surrogate even when lymph nodes are not presented with tumor sample that is a real challenging shortcoming in veterinary medicine [40].

Another important finding was a positive correlation between CSCs and lymph node involvement, which was in line with Abbass et al. results who found strong association among CSCs, lymph node involvement, and distant metastases [44]. Given the complex nature of cancer dissemination processes particularly after apparently successful treatment, exclusively, cells harboring stem-like qualities are able to survive and gain access to lymph nodes and distant niches by overwhelming immune system surveillance and shearing stresses during circulation [45]. As regional lymph node positivity has been associated with poor prognosis and subsequent metastases, multiple studies have focused on the presence of CSCs in primary and secondary tumors. They have found a significant relatioonship between this subpopulation and higher lymphatic spread of tumors, as a major route of dissemination, which is in line with our finding [45-47].

There are similarities between the results obtained in this study regarding significant the positive correlation between EMT and lymph node involvement and those described 
by Jones et al. and Kariri et al. [48,49]. Additionally, Chen et al. highlighted the role of EMT in lymph node metastases by blocking the main transcription factors of EMT which leads to reduction in invasive ability of laryngeal cancer cells [21].

In other types of carcinomas, EMT is considered as a prognostic factor which has a strong correlation with other prognosticators including pathologic lymph node status, tumor grades, and tumor size among others [50]. Despite of being single cells circulating through the whole body, EMT confers these motile cells an instinct resistance to apoptosis so this cellular plasticity contributes to increased invasiveness and malignant behavior [51].

Interestingly, the present work found that concurrent presence of CSCs and EMT had significant relationship with lymph node metastases. This can be explained by sharing almost similar pivotal molecular networks and signaling pathways in both phenotype plasticity and stemness which can synergistically result in higher grade of metastatic properties and lymph node involvement [52]. Several studies have suggested that the metastatic capacity of breast cancers is conducted by CSCs in that cells found in lymph node metastases and bone marrow of these patients showed CSC enrichment $[53,54]$.

\section{CONCLUSION}

The findings of this work highlighted the practical prognostic significance of histopathologic characteristics including VM and MGP in predicting patients' outcome. Additionally, described criteria can provide further evidence supporting prognostic role of CSCs when comparing to common prognosticators, namely LVI and lymph node involvement in CMGCs. The findings of this study have a number of important implications for future practice.

\section{Authors' contributions}

HM designed and supervised the experiment. AY, MSHB, PA, and NP performed the experiment. HM, FKH, and SM performed the statistical analysis. ZA, GCH, MB, and $\mathrm{KV}$ wrote the manuscript in consultation with HM. All authors read and approved the final manuscript.

\section{Declaration of conflicting interests}

The author(s) declared no potential conflicts of interest with respect to the research, authorship, and/or publication of this article. 


\section{REFERENCES}

1. Nguyen F, Peña L, Ibisch C, Loussouarn D, Gama A, Rieder N, Belousov A, Campone $\mathrm{M}$, Abadie J: Canine invasive mammary carcinomas as models of human breast cancer. Part 1: natural history and prognostic factors. Breast cancer research and treatment 2018, 167:635-648.

2. Rasotto R, Zappulli V, Castagnaro M, Goldschmidt MH: A retrospective study of those histopathologic parameters predictive of invasion of the lymphatic system by canine mammary carcinomas. Veterinary pathology 2012, 49:330-340.

3. Gray M, Meehan J, Martínez-Pérez C, Kay C, Turnbull AK, Morrison LR, Pang LY, Argyle D: Naturally-occurring canine mammary tumors as a translational model for human breast cancer. Frontiers in oncology 2020,10.

4. Marconato L, Facchinetti A, Zanardello C, Rossi E, Vidotto R, Capello K, Melchiotti E, Laganga P, Zamarchi R, Vascellari M: Detection and prognostic relevance of circulating and disseminated tumour cell in dogs with metastatic mammary carcinoma: a pilot study. Cancers 2019, 11:163.

5. Ayob AZ, Ramasamy TS: Cancer stem cells as key drivers of tumour progression. Journal of biomedical science 2018, 25:1-8.

6. Paul CD, Mistriotis P, Konstantopoulos K: Cancer cell motility: lessons from migration in confined spaces. Nature Reviews Cancer 2017, 17:131-140.

7. Ye F, Yu P, Li N, Yang A, Xie X, Tang H, Liu P: Prognosis of invasive micropapillary carcinoma compared with invasive ductal carcinoma in breast: A meta-analysis of PSM studies. The Breast 2020, 51:11-20.

8. Lin H, Hong Y, Huang B, Liu X, Zheng J, Qiu S: Vimentin Overexpressions induced by cell hypoxia promote Vasculogenic mimicry by renal cell carcinoma cells. BioMed research international 2019, 2019.

9. Zhang JG, Zhou HM, Zhang X, Mu W, Hu JN, Liu GL, Li Q: Hypoxic induction of vasculogenic mimicry in hepatocellular carcinoma: role of HIF-1 $\alpha$, RhoA/ROCK and Rac1/PAK signaling. BMC cancer 2020, 20:1-3.

10. Strouhalova K, Přechová M, Gandalovičová A, Brábek J, Gregor M, Rosel D: Vimentin intermediate filaments as potential target for cancer treatment. Cancers 2020, 12:184.

11. Te Boekhorst V, Friedl P: Plasticity of cancer cell invasion-Mechanisms and implications for therapy. Advances in cancer research 2016, 132:209-64.

12. Jahanban-Esfahlan R, Seidi K, Manjili MH, Jahanban-Esfahlan A, Javaheri T, Zare P: Tumor cell dormancy: threat or opportunity in the fight against cancer. Cancers 2019, 11:1207.

13. Mani SA, Guo W, Liao MJ, Eaton EN, Ayyanan A, Zhou AY, Brooks M, Reinhard F, Zhang CC, Shipitsin M, Campbell LL: The epithelial-mesenchymal transition generates cells with properties of stem cells. Cell 2008, 133:704-715.

14. Strati A, Nikolaou M, Georgoulias V, Lianidou ES: Prognostic significance of TWIST1, CD24, CD44, and ALDH1 transcript quantification in EpCAM-positive circulating tumor cells from early stage breast cancer patients. Cells 2019, 8:652.

15. Rybicka A, Król M; Identification and characterization of cancer stem cells in canine mammary tumors. Acta Veterinaria Scandinavica 2016, 58:1-7.

16. Maroufi NF, Amiri M, Dizaji BF, Vahedian V, Akbarzadeh M, Roshanravan N, Haiaty S, Nouri M, Rashidi MR: Inhibitory effect of melatonin on hypoxia-induced vasculogenic 
mimicry via suppressing epithelial-mesenchymal transition (EMT) in breast cancer stem cells. European Journal of Pharmacology 2020, 881:173282.

17. Meuten DJ. Tumors in domestic animals. 5th ed. Wiley Blackwell; 2016. pp. 723-765.

18. Clemente M, Perez-Alenza MD, Illera JC, Peña L: Histological, immunohistological, and ultrastructural description of vasculogenic mimicry in canine mammary cancer. Veterinary Pathology 2010, 47:265-274.

19. Hujanen R, Almahmoudi R, Karinen S, Nwaru BI, Salo T, Salem A: Vasculogenic mimicry: a promising prognosticator in head and neck squamous cell carcinoma and esophageal cancer? a systematic review and meta-analysis. Cells 2020, 9:507.

20. Mahooti S, Porter K, Alpaugh ML, Ye Y, Xiao Y, Jones S, Tellez JD, Barsky SH: Breast carcinomatous tumoral emboli can result from encircling lymphovasculogenesis rather than lymphovascular invasion. Oncotarget 2010, 1:131.

21. Chen J, Chen S, Zhuo L, Zhu Y, Zheng H: Regulation of cancer stem cell properties, angiogenesis, and vasculogenic mimicry by miR-450a-5p/SOX2 axis in colorectal cancer. Cell death \& disease 2020, 11:1-3.

22. Prado MC, Macedo SD, Guiraldelli GG, de Faria Lainetti P, Leis-Filho AF, Kobayashi PE, Laufer-Amorim R, Fonseca-Alves CE: Investigation of the prognostic significance of vasculogenic mimicry and its inhibition by sorafenib in canine mammary gland tumors. Frontiers in oncology 2019, 9:1445.

23. Xu J, Zhang Y, Wang Y, Tao X, Cheng L, Wu S, Tao Y: Correlation of KAI1, CD133 and vasculogenic mimicry with the prediction of metastasis and prognosis in hepatocellular carcinoma. International journal of clinical and experimental pathology 2018, 11:3638.

24. Andonegui-Elguera MA, Alfaro-Mora Y, Cáceres-Gutiérrez R, Caro-Sánchez CH, Herrera LA, Díaz-Chávez J: An Overview of Vasculogenic Mimicry in Breast Cancer. Frontiers in oncology 2020, 10.

25. Lee SY, Jeong EK, Ju MK, Jeon HM, Kim MY, Kim CH, Park HG, Han SI, Kang HS: Induction of metastasis, cancer stem cell phenotype, and oncogenic metabolism in cancer cells by ionizing radiation. Molecular cancer 2017, 16:1-25.

26. Zhang X, Xing C, Guan W, Chen L, Guo K, Yu A, Xie K: Clinicopathological and prognostic significance of nestin expression in patients with breast cancer: a systematic review and meta-analysis. Cancer cell international 2020, 20:1-7.

27. Cao Z, Bao M, Miele L, Sarkar FH, Wang Z, Zhou Q: Tumour vasculogenic mimicry is associated with poor prognosis of human cancer patients: a systemic review and metaanalysis. European journal of cancer 2013, 49:3914-3923.

28. Wu Q, Wang J, Liu Y, Gong X: Epithelial cell adhesion molecule and epithelial-mesenchymal transition are associated with vasculogenic mimicry, poor prognosis, and metastasis of triple negative breast cancer. International journal of clinical and experimental pathology 2019, 12:1678.

29. Li S, Li Q: Cancer stem cells and tumor metastasis. International journal of oncology 2014, 44:1806-12.

30. Ahmadi SA, Moinfar M, Moghaddam KG, Bahadori M: Practical application of angiogenesis and vasculogenic mimicry in prostatic adenocarcinoma. Archives of Iranian medicine 2010, 13:498-503.

31. Zhao XL, Du J, Zhang SW, Liu YX, Wang X, Sun BC: A study on vasculogenic mimicry in hepatocellular carcinoma. Zhonghua gan zang bing za zhi= Zhonghua ganzangbing zazhi= Chinese journal of hepatology 2006, 14:41-44. 
32. Aleskandarany MA, Sonbul SN, Mukherjee A, Rakha EA: Molecular mechanisms underlying lymphovascular invasion in invasive breast cancer. Pathobiology 2015, 82:113-23.

33. Lavenus SB, Tudor SM, Ullo MF, Vosatka KW, Logue JS: A flexible network of vimentin intermediate filaments promotes migration of amoeboid cancer cells through confined environments. Journal of Biological Chemistry 2020, 295:6700-6709.

34. Daubriac J, Han S, Grahovac J, Smith E, Hosein A, Buchanan M, Basik M, Boucher Y: The crosstalk between breast carcinoma-associated fibroblasts and cancer cells promotes RhoA-dependent invasion via IGF-1 and PAI-1. Oncotarget 2018, 9:10375.

35. Vorotnikov AV, Tyurin-Kuzmin PA: Chemotactic signaling in mesenchymal cells compared to amoeboid cells. Genes \& diseases 2014, 1:162-73.

36. Yang YL, Liu BB, Zhang X, Fu L: Invasive micropapillary carcinoma of the breast: an update. Archives of pathology \& laboratory medicine 2016, 140:799-805.

37. Lee JH, Kim JH, Choi JW, Kim YS: The presence of a micropapillary component predicts aggressive behaviour in early and advanced gastric adenocarcinomas. Pathology 2010, 42:560-563.

38. Brown JM, Wasson MC, Marcato P: The missing Lnc: the potential of targeting triplenegative breast cancer and cancer stem cells by inhibiting long non-coding RNAs. Cells 2020, 9:763.

39. Abadie J, Chocteau F, Loussouarn D, Nguyen F: Proposal for a Histological Staging System of Mammary Carcinomas in Dogs and Cats. Part 1: Canine Mammary Carcinomas. Frontiers in Veterinary Science 2019, 6:388.

40. Liao GS, Hsu HM, Chu CH, Hong ZJ, Fu CY, Chou YC, Golshan M, Dai MS, Chen TW, De-Chian C, Tsai WC: Prognostic role of lymphovascular invasion and lymph node status among breast cancer subtypes. Journal of Medical Sciences 2018, 38:54.

41. Shi Y, Su WJ, Dai GZ: Development of a risk-stratification scoring system for predicting lymphovascular invasion in breast cancer. BMC cancer 2020, 20:94.

42. Ragage F, Debled M, MacGrogan G, Brouste V, Desrousseaux M, Soubeyran I, Tunon de Lara C, Mauriac L, de Mascarel I: Is it useful to detect lymphovascular invasion in lymph node-positive patients with primary operable breast cancer?. Cancer 2010, 116:3093-3101.

43. El Abbass KA, Abdellateif MS, Gawish AM, Zekri AR, Malash I, Bahnassy AA: The role of breast cancer stem cells and some related molecular biomarkers in metastatic and nonmetastatic breast cancer. Clinical breast cancer 2020, 20:e373-84.

44. Liu Y, Yang M, Luo J, Zhou H: Radiotherapy targeting cancer stem cells "awakens" them to induce tumour relapse and metastasis in oral cancer. International journal of oral science 2020, 12:1-12.

45. Szczubiał M, Łopuszynski W: Prognostic value of regional lymph node status in canine mammary carcinomas. Veterinary and comparative oncology 2011, 9: 296-303.

46. Wei W, Hu H, Tan H, Chow LW, Yip AY, Loo WT: Relationship of CD44+ CD24-/low breast cancer stem cells and axillary lymph node metastasis. In Journal of translational medicine 2012, 10:1-6.

47. Jones BC, Kelley LC, Loskutov YV, Marinak KM, Kozyreva VK, Smolkin MB, Pugacheva EN: Dual targeting of mesenchymal and amoeboid motility hinders metastatic behavior. Molecular Cancer Research 2017, 15:670-682.

48. Kariri YA, Aleskandarany MA, Joseph C, Kurozumi S, Mohammed OJ, Toss MS, Green AR, Rakha EA: Molecular Complexity of Lymphovascular Invasion: The Role of Cell Migration in Breast Cancer as a Prototype. Pathobiology 2020, 87:218-231. 
49. Cao R, Yuan L, Ma B, Wang G, Qiu W, Tian Y: An EMT-related gene signature for the prognosis of human bladder cancer. Journal of cellular and molecular medicine 2020, 24:605-617.

50. Parvani JG, Schiemann WP: Sox4, EMT programs, and the metastatic progression of breast cancers: mastering the masters of EMT. Breast Cancer Research 2013, 15:1-3.

51. Garg M: Epithelial, mesenchymal and hybrid epithelial/mesenchymal phenotypes and their clinical relevance in cancer metastasis. Expert Reviews in Molecular Medicine 2017, 19:113.

52. Luo A, Xu Y, Li S, Bao J, Lü J, Ding N, Zhao Q, Fu Y, Liu F, Cho WC, Wei X: Cancer stem cell property and gene signature in bone-metastatic Breast Cancer cells. International journal of biological sciences 2020, 16:2580-2594.

53. Velasco-Velázquez MA, Popov VM, Lisanti MP, Pestell RG: The role of breast cancer stem cells in metastasis and therapeutic implications. The American journal of pathology 2011, 179:2-11.

\title{
POVEZANOST MATIČNIH ĆELIJA TUMORA I HISTOPATOLOŠKIH KARAKTERISTIKA ZA ODREĐIVANJE PROGNOZE KARCINOMA MLEČNE ŽLEZDE PASA
}

\author{
Havva MARZBAN, Gelareh CHAMANI, Fariba KHAKI, Parnian AMINI, \\ Nastaran PEDRAM, Zeinab ASGHARI, Mohammadreza BOROOMAND, \\ Samira MORADI, Artimes YAHYAEI, Mersedeh Sadat HOSSEIN BOROUJERDI, \\ Kamyab VALINEZHAD
}

Cilj rada je bio evaluacija prognostičkog potencijala histopatoloških karakteristika kancera matičnih ćelija (CSCs), epitelno-mezenhimske tranzicije (EMT) u odnosu na status limfnih čvorova i limfovaskularne invazije (LVI) u slučajevima karcinoma mlečne žlezde kod pasa (CMGCs). Predpostavljeno je da su CSCs glavni uzroci tumorogeneze, neuspešne terapije i ponovnog pojavljivanja, što predstavlja mali segment svih slučajeva tumora. Obavljena je evaluacija mikropapilarne slike rasta (MGP), infiltracije u okolna tkiva (IST) i vaskulogene mimikrije (VM) pri čemu su korišćeni histološki preparati (hematoksilin-eozin tehnika bojenja), dobijeni iz 26 parafinskih uzoraka tumora. Urađena je histološka procena svih limfnih čvorova. Pored toga, obavljena je imunohistohemijska analiza u odnosu na ekspresiju vimentina kao indikatora EMT koji je dobro poznat mehanizam nastanka metastaza kao i detekcija CSC putem analize CD44, CD24 i ALDH1. Analiza rezultata ispitivanja je pokazala značajnu povezanost između CSCs $(\mathrm{P}=0,037)$, IST i LVI $(\mathrm{P}=0,013)$, statusa limfnih čvorova i CSC $(\mathrm{P}=0,0001)$, statusa limgnih čvorova i IMT (P=0,003), IST i LV( ( $\mathrm{P}=0,05)$, VM i LVI $(\mathrm{P}=0,01)$ VM i statusa limfnih čvorova $(\mathrm{P}=0,007)$ i LVI i statusa limfnih čvorova $(\mathrm{P}=0,04)$. Rezultati 
ukazuju na prognostički značaj MG, VM i CSC u odnosu na potvrđene prognostičke markere, uključujući LVI i uključenost limfnih čvorova u slučaju CMGS-a. 